\title{
Duplication of Gallbladder
}

\author{
Bhaskar Chintakayala* \\ Department of General and Minimal access surgery, India
}

Received: May 07, 2018; Published: October 15, 2018

*Corresponding author: Bhaskar Chintakayala, General surgeon resident, Maharaja Agrasen Hospital, Department of General and Minimal access surgery, New Delhi, India; Email: bhaskar.chintakayala@gmail.com

\begin{abstract}
Anatomical variations of gallbladder are being rare entity and duplication is one of the variants with two funds of gallbladder communication through a common channel cystic duct to the bile duct. Incidence of Gallbladder duplication has been reported 1:4000 in the literature. We report a case of incidental finding of gall bladder duplication during laparoscopic cholecystectomy for symptomatic cholelithiasis with both the fundus harbouring gallstones with a single cystic duct and two cystic arteries. Surgery was successful with both gallbladders removed and no postoperative complication reported. This case emphasises the need for removal of both the gallbladders in the same setting with recognition of possible vascular and biliary aberrant anatomy to avoid and complication during surgery.
\end{abstract}

Keywords:Duplicated gallbladder; Aberrant biliary anatomy;Fundus duplication;Laparoscopic cholecystectomy

\section{Introduction}

Aberrant anatomy of biliary structures like duplication of gallbladder is one of the rare presentations occurring in 1:38004000 births [1]. These congenital anomalies pose a definite risk of biliary injury during operative interventions like laparoscopic cholecystectomy. Precise diagnosis pre-operatively is required for precise plan of management and to make sure both the gallbladders are removed completely without complications. As these anomalies are frequently associated with stone formation due to inadequate bile drainage. Laparoscopic cholecystectomy is the treatment of choice.

\section{Case Report}

\begin{tabular}{|l|c|}
\hline Vesica fellea divisa & \multicolumn{2}{|c|}{ Vesica fellea duplex } \\
\hline & Y-shaped type
\end{tabular}

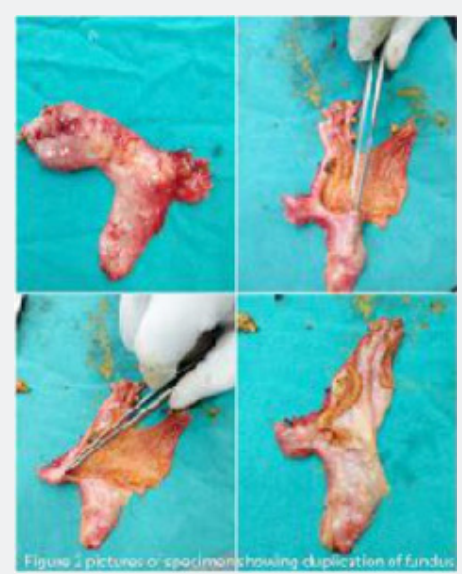

Figure 1: Boyden'sclassificationcongenitalduplicationofgallbladder. 
We report a case of incidentally finding of duplicated gallbladder during intra operative procedure of laparoscopic cholecystectomy for symptomatic cholelithiasis in a 38yr lady. She presented to the OPD with complaints of recurrent pain in the right upper quadrant region for 4 months with fatty meal intake. Her medical history was not contributory and no history any interventions in the past. Clinically her abdomen was soft, no tenderness or distention with no palpable lumps and no signs of jaundice. Her blood workup was normal, and USG revealed a large dissented gallbladder with multiple calculi and sludge with no signs of cholecystitis. Patient was taken up for laparoscopic cholecystectomy after taking proper informed consent. After introduction of scope we noticed a usually large gallbladder upon exploration duplication of fundus of gallbladder was evident opening through a common channel cystic duct as shown in (Figure 1). During calot's dissection two cystic arteries were encountered and were carefully clipped and divided. The common cystic duct was clipped and divided, and gallbladder extracted with no complications. Patient recovered well and was discharged the next day and she was followed further and no complication were reported.

\section{Discussion}

\section{Incidence}

Congenital variation of anatomy of gallbladder are rare. Duplication of gallbladder is one such variant occurring in 1 of every 3800-4000 births [1]. It is thought to be due to exuberant budding of the developing biliary tree during the division of caudal bud of hepatic diverticulum. The first reported human case was noted in a sacrificial victim of Emperor Augustus in 31 BC. It is important to know because of the frequent association of cystic duct and artery variations [2-4].

\section{Etiology}

According to Boyden's classification in (Figure 1)

1. Vesical fellea divisa (bilobed or bifid gallbladder, double gallbladder with a common neck).

2. Vesical fellea duplex (double gallbladder with two cystic ducts).

a) Y-shaped type (the two cystic ducts uniting before entering the common bile duct).

b) H-shaped type (ductular type, the two cystic ducts entering separately into the biliary tree).

Of these vesical fellea duplex is true duplication and is more common. The anatomical location may vary but share a common peritoneal coat and are usually beside each other or one could be entirely intrahepatic or sub hepatic. True gall bladder duplications may share a common cystic duct, arterial supply or have separate cystic ducts and blood supply [5,6].

\section{Clinical Features}

Duplicated gallbladder is a rare anomaly that cannot be accurately assessed, since the only cases which have been identified are those that became symptomatic or were encountered as incidental findings during surgery, imaging studies or at autopsy. Usually present with similar complaints as with normal gallbladder disease and as there is no significant risk for subsequent disease, prophylactic cholecystectomy in an asymptomatic patient with gallbladder duplication is not recommended.

\section{Diagnosis}

Gallbladder duplication can be detected preoperatively by imaging studies. USG is generally the first choice of imaging modality in patients with suspected biliary disease. USG may diagnose gallbladder duplication if the viscera are located separately may suggest a double gallbladder, the cystic duct is usually not identified, and it is often impossible, as in our case, to distinguish bilobed gallbladder from a distended gallbladder. MRI or a CECT would be more valuable in visualising duplicated gallbladder preoperatively $[7,8]$.

\section{Management}

Laparoscopic cholecystectomy would be advised for patients with symptomatic cholelithiasis with preoperatively detached duplicated gallbladder with no evidence for intervention in asymptomatic incidentally discovered duplicated gallbladder.

\section{Conclusion}

Duplication of gallbladder is a rare congenital anomaly which requires attention as it is often associated with other aberrant anatomy cystic duct hepatic and cystic artery. Careful delineation of anatomy preoperative or intraoperatively may be required in such cases.

\section{References}

1. Boyden EA (1926) The accessory gallbladder: an embryological and comparative study of aberrant biliary vesicles occuring in man and the domestic mammals. American Journal of Anatomy 38(2): 177-231.

2. Udelsman R, Sugarbaker PH (1985) Congenital duplication of the gallbladder associated with an anomalous right hepatic artery," Am J Surg 149(6): 812-815.

3. Lamah M, Karanjia ND, Dickson GH (2001) Anatomical variations of the extrahepatic biliary tree: review of the world literature. Clin Anat 14(3):167-172.

4. Kothari PR, Kumar T, Jiwane A, Paul S, Kutumbale R, et al. (2005) Unusual features of gall bladder duplication cyst with review of the literature. Pediatr Surg Int 21(7): 552-554.

5. Horattas MC (1998) Gallbladder duplication and laparoscopic management. J Laparoendosc Adv Surg Tech A 8(4): 231-235.

6. Miyajima N, Yamakawa T, Varma A, Uno K, Ohtaki S, et al. (1995) Experience with laparoscopic double gallbladder removal. Surgical Endoscopy 9(1): 63-66.

7. Ozgen A, Akata D, Arat A, Demirkazik FB, Ozmen MN, et al. (1999) Gallbladder duplication: imaging findings and differential considerations. Abdom Imaging 24(3): 285-288.

8. Mazziotti S, Minutoli F, Blandino A, Vinci S, Salamone I, et al. (2001) Gallbladder duplication: MR cholangiography demonstration. Abdom Imaging 26(3): 287-289. 
(CC) (i) This work is licensed under Creative Commons Attribution 4.0 Licens BY DOI: 10.19080/OAJS.2018.09.555773
Your next submission with Juniper Publishers will reach you the below assets

- Quality Editorial service

- Swift Peer Review

- Reprints availability

- E-prints Service

- Manuscript Podcast for convenient understanding

- Global attainment for your research

- Manuscript accessibility in different formats ( Pdf, E-pub, Full Text, Audio)

- Unceasing customer service

Track the below URL for one-step submission https://juniperpublishers.com/online-submission.php 